\title{
Assessment by Ames test and comet assay of toxicity potential of polymer used to develop field-capable rapid-detection device to analyze environmental samples
}

\author{
Amanda Hebert • Michelle Bishop • \\ Dhiman Bhattacharyya • Karen Gleason • \\ Stephen Torosian
}

Received: 9 October 2014/ Accepted: 15 October 2014/Published online: 2 November 2014

(C) The Author(s) 2014. This article is published with open access at Springerlink.com

\begin{abstract}
There is need for devices that decrease detection time of food-borne pathogens from days to real-time. In this study, a rapid-detection device is being developed and assessed for potential cytotoxicity. The device is comprised of melt-spun polypropylene coupons coated via oxidative chemical vapor deposition (oCVD) with 3,4Ethylenedioxythiophene (EDOT), for conductivity and 3-Thiopheneethanol (3TE), allowing antibody attachment. The Ames test and comet assay have been used in this study to examine the toxicity potentials of EDOT, 3TE, and polymerized EDOT-co-3TE. For this study, Salmonella typhimurium strain TA1535 was used to assess the mutagenic potential of EDOT, 3TE and the copolymer. The average mutagenic potential of EDOT, 3TE and copolymer was calculated to be $0.86,0.56$, and 0.92 , respectively. For mutagenic potential, on a scale from 0 to 1 , close to 1 indicates low potential for toxicity, whereas a value of 0 indicates a high potential for toxicity. The comet assay is a single-cell gel electrophoresis technique that is widely used for this purpose. This assay measures toxicity based on the area or intensity of the comet-like shape that DNA fragments produce when DNA damage has occurred. Three cell lines were assessed; FRhK-4, BHK-21, and Vero cells.
\end{abstract}

A. Hebert $\cdot$ S. Torosian $(\bowtie)$

US Food and Drug Administration, Winchester Engineering and Analytical Center, Winchester, MA 01890, USA

e-mail: stephen.torosian@fda.hhs.gov

M. Bishop

US Food and Drug Administration, National Center for

Toxicology Research, Jefferson, AR 72079, USA

D. Bhattacharyya $\cdot$ K. Gleason

Department of Chemical Engineering, Massachusetts Institute of

Technology, Cambridge, MA 02139, USA
After averaging the results of all three strains, the tail intensity of the copolymer was $8.8 \%$ and tail moment was 3.0 , and is most similar to the untreated control, with average tail intensity of $5.7 \%$ and tail moment of 1.7. The assays conducted in this study provide evidence that the copolymer is non-toxic to humans.

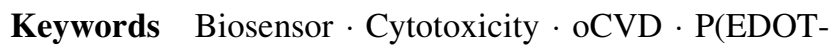
co-3TE)

\section{Introduction}

Presently, there is potential to drastically decrease the time it takes to carry out and confirm food pathogen assays. Utilizing a rapid-detection device could prevent outbreaks by confirming the presence of a pathogen prior to distribution or ingestion. Designing a real-time biosensor device to detect pathogens greatly decreases the chance of an outbreak, and even if an outbreak still occurs, this device could confirm the cause of the infection. Since the benefits of such a device are clear, a determination of possible toxicity effects created from its use should be determined.

Many food-borne pathogens are spread from surface contact, which makes environmental swabs an important part of hazard analysis critical control points (HACCP) at food manufacturing companies. Over 1,000 environmental swabs are used each year at just one large facility of a major United States food processer (Hood 2013). There are many food companies in the US alone that could significantly benefit from a real-time device that would provide rapid and highly sensitive results.

A prototype device has previously been generated that employed polypropylene microfibers coated with polypyrrole and functionalized with antibodies for Escherichia coli

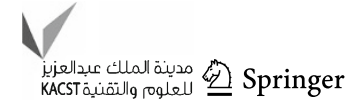


O157:H7 (McGraw et al. 2012b). The conductivity of the functionalized membrane was measured over time and could detect as few as 0-9 CFU/ml (McGraw et al. 2012b).

Desirable characteristics of such a device for detection of bacteria include being durable with high surface area microfiber material. Larger surface area allows greater attachment of biomolecules, which means this biosensor will have better sensitivity (Bhattacharyya et al. 2011, 2012; McGraw et al. 2012a). The melt-spun polypropylene will be coated on both sides with a very thin layer of conducting polymers, created from the monomers 3,4ethylenedioxythiophene (EDOT) and 3-thiopheneethanol (3TE) on a microfibrous mat via oxidative chemical vapor deposition (oCVD). Iron(III) chloride is heated in a vacuum to allow deposition on the fibers. This is followed by heating the monomer mixture in a vacuum allowing single molecules to be polymerized from the iron(III) chloride deposited earlier.

After deposition, some of the samples were exposed to an acid rinse dopant exchange, in this study it was sulfuric acid rinse, then methanol, both of which are used to remove excess iron(III) chloride or monomers, which increases the conductivity and improves sensitivity (Bhattacharyya et al. 2011, 2012; Howden et al. 2013). By determining the toxicity potential of the chemicals in this study, it can be decided whether the polymerized copolymer (P(EDOT-co3TE)) coating is safe for use or whether another composition would have less risk.

Some investigators looked at cell viability using phosphate buffered saline or polystyrene sulfonate for dopant exchange. None of these studies demonstrated significant change in viability. However, there are more subtle longrange effects that do not overtly express as loss of viability but may have effects via long-term exposure (Luo et al. 2008; Miriani et al. 2008; Asplund et al. 2009; Moral-Vico et al. 2014).

These viability studies were carried out on PEDOT created by electrodeposition. There have been no published in vitro toxicity studies on the chemicals used for nanolayer oCVD deposition nor on the copolymer P(EDOT-co3TE). A tenet of nanomaterials is that they often take on diverse characteristic(s) peculiar to the nano state. It is prudent therefore to examine toxicity potential of such materials. If current chemical composition of the coating was determined to be cytotoxic or environmentally hazardous, other options to reduce cytotoxic effect could be explored. Among possible options would be modifying the EDOT to 3TE ratio, using 3-Thiophene acetic acid and polypyrrole (McGraw et al. 2012a) or other conductive copolymers.

The Ames test determines mutagenic potential of each test chemical by exposing them to mutated strains of $\mathrm{Sal}$ monella typhimurium that need histidine to survive. The
Salmonella grows on minimal media and has a trace amount of histidine in a top agar. Either a phosphate buffer or a pooled rat liver S9 fraction that is mixed with cofactors is used for metabolic activation (Ames et al. 1973a, 1973b; Mortelmans and Zeiger 2000; Wessner et al. 2000; Hakura et al. 2003, 2005; Howden et al. 2013). The amount of S9 fraction that is added to the mix will greatly affect the amount of growth as well. Research on numerous known mutagens has demonstrated that they will have a higher count of colony forming units (CFU) than nonmutagenic chemicals tested with a strain (Hakura et al. 2005). If the percentage of S9 fraction in the mix is too low, there is no significant difference in the negative and positive controls (Forster et al. 1980). If the test chemical has the same heavy growth using various concentrations as the control mutagen, then the test chemical is considered to be mutagenic, and potentially carcinogenic.

When S9 mix is used, each strain uses the same known mutagen as a positive control. Using phosphate buffer instead of S9 mix means each strain will be tested with a different known mutagen as a control and compare against the test chemicals. The strain used in this study was TA1535 but other strains that are known to be tested in this assay include TA1537, TA1538, and TA98. Each has a different type of mutation. When TA1535 undergoes a reverse mutation, a base-pair substitution has occurred (Mortelmans and Zeiger 2000). By exposing the mutated strain to a known mutagen, there is a high amount of CFU since many reverse mutations occur. Without the mutagen, there are much fewer colonies due to the randomness of a mutation. A test chemical is considered a mutagen when the mutagenic frequency is above 2.0 or significantly lower than 1.0. This number is determined by dividing the mean CFU of the test chemical by the mean of the CFU for the untreated sample (Ames et al. 1973a, 1973b; Forster et al. 1980; Mortelmans and Zeiger 2000; Wessner et al. 2000; Hakura et al. 2003, 2005). By comparing the controls to the test chemicals, it can be determined whether they are potentially harmful.

The comet assay uses single-cell gel electrophoresis. A small amount of cells that are in agarose gel are lysed, the DNA unwinds, and then they undergo gel electrophoresis (Trevigen Inc. 2012). Once these cells are stained with SYBR green or SYBR gold, the comet-tail shape from the cell damage becomes apparent in epifluorescence microscopy and can be scored. Alkaline reagents are used because it is suggested that this is a more sensitive treatment that will detect single- and double-strand breaks (Speit and Hartmann 2006; Trevigen Inc. 2012). The larger the comet tail, the more DNA damage has occurred. After exposing cells to test chemical and there is little or no change in the cells, then the chemical is considered to have a very low chance of toxicity. 
Numerous articles have discussed the comet assay, over 7,400 on PubMed alone, emphasizing its reliability and justifying the high frequency of use. The cell lines tested in this study are FRhK-4 and BHK-21. The BHK-21 cell line was also electroporated. Testing different cell lines derived from a variety of organisms aids in determining the potential for genotoxic affects of chemical exposure to kidneys (Genies et al. 2013). The three cell lines were from a variety of organisms and life stages. In this study, FRhK is fetal rhesus monkey kidney cells, BHK-21 is baby hamster kidney cells and Vero is African green monkey kidney cells. The cytotoxicity concerns for the chemicals used in this biosensor have been raised since there has been no previous studies addressing them in vitro.

For comprehensive comet analysis, software can be used to statistically analyze the data by viewing the slides using an epifluorescence microscope. It is important to consider how much of the original cell is intact and how much of the cell forms a comet (Olive et al. 1990a, 1990b; Olive and Banath 1995). Scoring the comets live with software gives highly accurate and quick results. When using comet assay IV software, several measurements can be instantly calculated and the results can be compared with the controls. It is critical to have these measurements when the cells look similar comparing various chemical treatments. It is important to consider how much of the original cell is intact and how much of the cell forms a comet. The high percentage of damaged cells indicates a great risk for toxicity.

After performing both Ames test and comet assay, the monomers show some potential of toxicity, but the deposited copolymer has a much lower potential, if at all. Based on current results, $\mathrm{P}$ (EDOT-co-3TE) coating has shown to be safe for use in the field and in food industries to prevent outbreaks.

\section{Materials and methods}

\section{Ames test}

S. typhimurium strain TA1535 was added to 3-ml overlay agar tube that consisted of agar, sodium chloride, and a histidine/biotin solution. Phosphate buffer $\mathrm{pH} 7.0$ was made. To every negative control overlay tube, $60 \mu$ of $S$. typhimurium and $500 \mu \mathrm{l}$ of phosphate buffer were added (Mortelmans and Zeiger 2000; Wessner et al. 2000). Each positive control tube had buffer, Salmonella and $100 \mu \mathrm{g} / \mathrm{ml}$ concentration of sodium azide. The control and test chemicals were plated in triplicate. The concentration of EDOT was $1.33 \mathrm{~g} / \mathrm{ml}$, and concentration of 3TE was $1.144 \mathrm{~g} / \mathrm{ml}$ were added to respective tubes. Deposited copolymer that was removed from a glass slide added to a microfuge tube containing glass beads and distilled water, then vortexed for $1 \mathrm{~min}$ at full speed. This created a relatively stable suspension of polymer with a range of sizes between 1 and $5 \mu \mathrm{m}^{2}$, however most particles were $1 \mu \mathrm{m}^{2}$ or less. There was $50 \mu \mathrm{l}$ of the test solution added to each tube. The overlay was added to Davis minimal agar. After 5-7 days of incubation at $35^{\circ} \mathrm{C}$, the plates were counted and the mutagenic potential was determined.

Removal of copolymer from glass slides

About twenty 500-750 $\mu \mathrm{m}$ diameter glass beads were added to a microfuge tube. Razor blades were sterilized and about $400 \mu \mathrm{l}$ of electroporation buffer or $1 \mathrm{X}$ phosphate buffered saline (PBS) was placed on the slide before scraping the slide with a sterile razor blade to collect the sample. After the sample was added to the microfuge tube, it was vortexed for $1 \mathrm{~min}$. The samples were placed at $4{ }^{\circ} \mathrm{C}$ for storage. The particles were analyzed using a confocal microscope and the most of the particle sizes ranged from $1 \mu \mathrm{m}^{2}$ or less. One glass slide of copolymer was used per $400 \mu \mathrm{l}$ of electroporation buffer. Since the thickness has been consistent with every deposition, this ensures that the same concentration of copolymer was used in each test.

\section{Electroporation}

The procedure given in the electroporator manual was used. The voltage was $139 \mathrm{~V}$, the amount of time $25 \mathrm{~ms}$, the interval 0 , the number 1 , and the droop $9 \%$. After this procedure most of the copolymer particles have an average area of about $1 \mu \mathrm{m}^{2}$ or less.

\section{CometAssay $^{\circledR}$}

Each cell line was grown in Dulbecco's modified eagle's medium (ATCC). Some of the BHK-21 cells were electroporated. They are passaged regularly so they are not $100 \%$ confluent when the comet assay is performed. The cells are removed from the flask first by rinsing with $37{ }^{\circ} \mathrm{C}$ 1X PBS (Sigma) two times, each time the cells were kept in the $5 \% \mathrm{CO}_{2}$ incubator for 1-2 min. Trypsin-Versene (Lonza) was added when it was time to remove the cells from the flask. The amount of time the cells were exposed to trypsin varies depending on the cell line. The alkaline protocol by Trevigen was followed. Lysis solution (Trevigen) was cooled at $4{ }^{\circ} \mathrm{C}$ prior to use. Approximately $1 \times 10^{5}$ cells in $1 \mathrm{X}$ PBS (Sigma) of each cell type were prepared and can be found at ATCC. The cells were counted using a hemocytomer and Trypan blue $(0.04 \%)$. Cells were spun at $250 \times g$ for $9 \mathrm{~min}$. Each slide was warmed in $37{ }^{\circ} \mathrm{C}$ incubator for at least $20 \mathrm{~min}$ to increase agarose adhesion. The LM agarose (Trevigen) was boiled

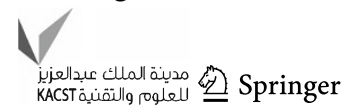


Table 1 Ames test

\begin{tabular}{lcrccl}
\hline Chemical added & $\begin{array}{l}\text { CFU/ } \\
\text { plate 1 }\end{array}$ & $\begin{array}{l}\text { CFU/ } \\
\text { plate 2 }\end{array}$ & $\begin{array}{l}\text { CFU/ } \\
\text { plate 3 }\end{array}$ & $\begin{array}{c}\text { Average } \\
\text { Mutagenic } \\
\text { frequency }\end{array}$ \\
\hline Sodium azide & 102 & 157 & 131 & 130 & 2.6 \\
$\begin{array}{l}\text { None (just } \\
\quad \text { Salmonella) }\end{array}$ & 47 & 59 & 44 & 50 & 1 \\
$\begin{array}{l}\text { Copolymer from } \\
\text { glass slide }\end{array}$ & 51 & 52 & 35 & 46 & 0.92 \\
$\begin{array}{l}\text { EDOT } \\
\text { 3TE }\end{array}$ & 35 & 62 & 33 & 43 & 0.86 \\
& 42 & 27 & 15 & 28 & 0.56
\end{tabular}

Mutagenic frequency is measured by dividing the test chemical CFU by the negative control (Salmonella) CFU

in a beaker for about $5 \mathrm{~min}$, then cooled in a $37{ }^{\circ} \mathrm{C}$ water bath for $20 \mathrm{~min}$. Each sample had $25 \mu \mathrm{l}$ of cells and $25 \mu \mathrm{l}$ of a chemical. For every sample, there was $500 \mu \mathrm{l}$ of LM agarose added to a $2 \mathrm{~mL}$ centrifuge tube. It was mixed gently by inversion, and then a 20 min treatment with the cells in LM agarose, hydrogen peroxide was kept at $4{ }^{\circ} \mathrm{C}$ and the other samples were kept in the $37{ }^{\circ} \mathrm{C}$ water bath for $20 \mathrm{~min}$. After the $20 \mathrm{~min}$ treatment, two $50 \mu \mathrm{l}$ samples were added to the CometSlide ${ }^{\mathrm{TM}}$ sample area. Cover slips were added to the agarose to keep the cells in a single plane. The slides were placed flat in the dark at $4{ }^{\circ} \mathrm{C}$ for $30 \mathrm{~min}$. The slides were immersed in $4{ }^{\circ} \mathrm{C}$ lysis solution for $45 \mathrm{~min}$. After draining the lysis solution, the freshly made alkaline unwinding solution was added, and the slides were immersed for $20 \mathrm{~min}$ at room temperature. About $850 \mathrm{ml}$ of alkaline electrophoresis solution was added to the CometAssay ${ }^{\circledR}$ ES unit, and the power supply was adjusted to $21 \mathrm{~V}$. The electrophoresis solution was drained, and the slides were immersed in $\mathrm{dH}_{2} \mathrm{O}$ twice for $5 \mathrm{~min}$, then $70 \% \mathrm{EtOH}$ for $5 \mathrm{~min}$. The samples were dried at $37{ }^{\circ} \mathrm{C}$ for $30 \mathrm{~min}$. The samples were stored in a desiccator at room temperature until they were ready for scoring. When it was time for scoring, $100 \mu \mathrm{SYBR}^{\circledR}$ gold solution was added to each circle of dried agarose and stained at room temperature for $30 \mathrm{~min}$ in the dark. The slides were tapped and rinsed with water. The slides were then dried completely at $37{ }^{\circ} \mathrm{C}$ and then viewed by epifluorescence microscopy, $(496 / 522 \mathrm{~nm})$. The slides were scored using comet assay IV system.

\section{Results}

Based on the strain Salmonella TA 1535 it is suggested that the polymerized copolymer, EDOT and 3TE have a mutagenic frequency below 1 , meaning it has little to no potential for cytotoxicity (Table 1). However, 3TE has a mutagenic frequency of significantly lower than 1 , at 0.56 .
The EDOT has a concentration of $1.33 \mathrm{~g} / \mathrm{ml}$ and 3TE has a concentration of $1.14 \mathrm{~g} / \mathrm{ml}$ (Figs. 1, 2, 3, 4, 5 and 6).

The mean $\%$ tail intensity and tail moment are indications of toxicity. The tail moment is calculated using the tail length and the fraction of total DNA in the tail. Higher tail moment means there was damage to the cell after exposure to the chemicals. Different cell types were used to get a wider range of results because these cell tissues are sensitive to damage. The mean $\%$ tail intensity is determined based on the amount of DNA breaks in the tail relative to the head.

*Vero cell images look very similar to FRhK-4 and BHK-21 cells but are not included. The images are available on request.

\section{Discussion and conclusion}

After the Ames test using strain S. typhimurium TA1535, the mutagenic frequency of $3 \mathrm{TE}$ was 0.56 , which indicates toxicity potential because it is so much lower than 1 . This suggests the chemical could be too toxic for the Salmonella to grow or the cells may have died after exposure. The mutagenic frequency of EDOT is 0.86 , which shows it may be toxic since it is still lower than 1 . The copolymer had a mutagenic frequency of 0.92 , which indicates that mutagenicity potential is very low, if any at all, because this means the CFU that occurred after the copolymer treatment was very similar to the untreated CFU.

The mean of all cell types' tail intensity and tail moment for the copolymer was $8.8 \%$ and mean tail moment was 3, very close to the untreated control which had a mean tail intensity of $5.7 \%$ and a mean tail moment of 1.7 . The hydrogen peroxide was significantly higher than all the treatments, which resulted in a tail intensity of $76.7 \%$ and tail moment of 43.8. Both the copolymer and untreated have much lower numbers than the EDOT which had $26 \%$ with 10.3 tail moment and 3TE which had a $30.2 \%$ tail intensity and the tail moment was 12 . Based on these results, it shows that not only was the tail intensity percentage and tail moment less in the copolymer compared to other treatments, but the numbers are very close to the untreated control. It is important to note that BHK-21 cells that were exposed to the copolymer had slightly higher toxicity than EDOT, it is still significantly lower tail moment and tail intensity than the hydrogen peroxide control. The BHK-21 cells that were electroporated with the copolymer that were viewed in epifluorescence microscope did not have comet software analysis, but had been viewed in the epifluorescence microscope showed the vast majority of cells that were not damaged during the comet assay. Based on the overall results from comet assay 
Fig. 1 FRhK-4 cells. 1

Untreated, 2 hydrogen peroxide treatment, 3 P(EDOT-CO-3TE) treatment, 4 EDOT treatment, 5 3TE treatment

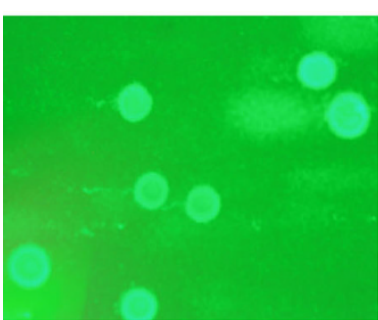

(1)

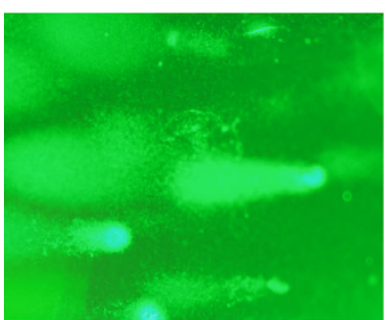

(4)

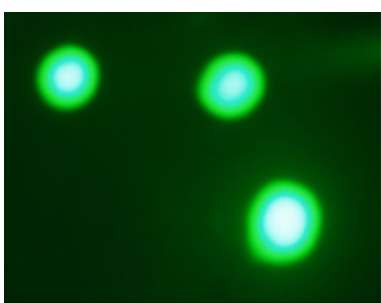

(1)

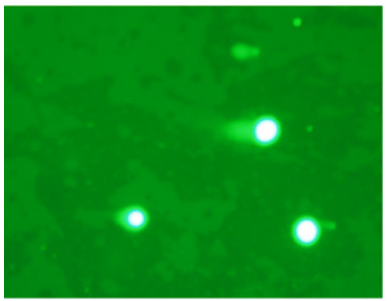

(4)

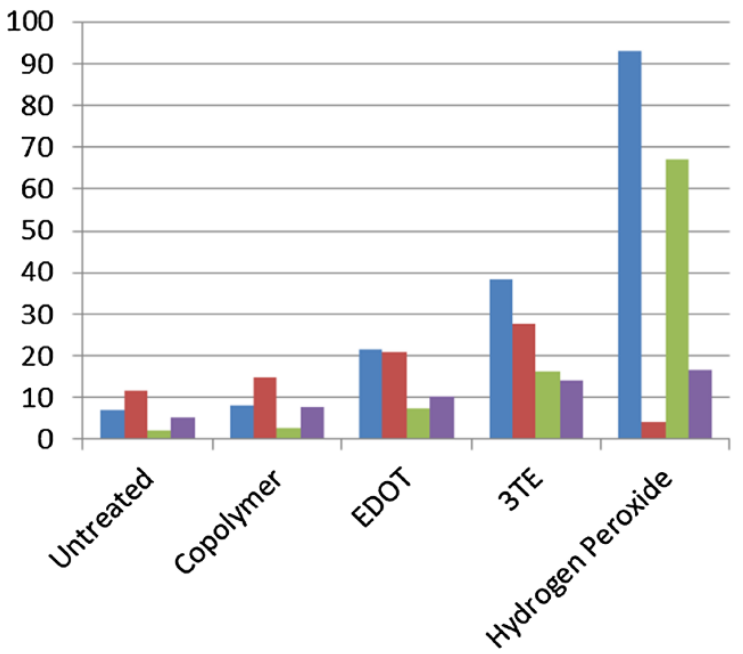

(2)

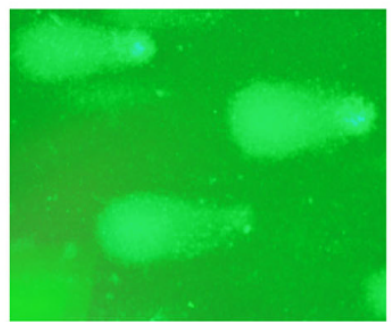

(5)

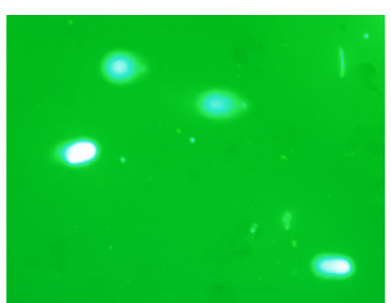

(2)

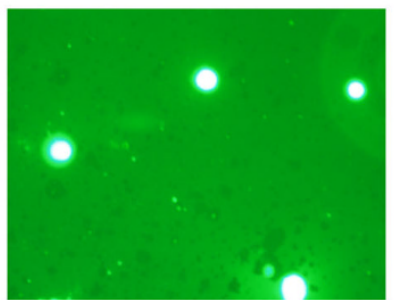

(5)

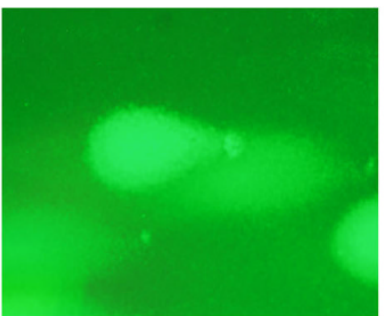

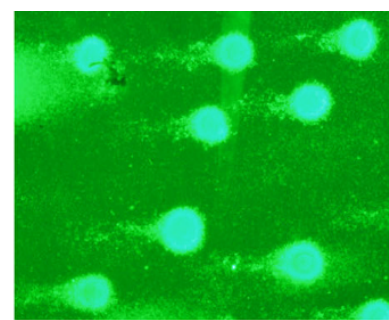

(3)
Fig. 3 Percent tail intensity and tail moment for FRhK-4 cells
Fig. 2 BHK-21 cells. 1 Untreated, 2 hydrogen peroxide 3TE treatment, 4 co-3TE) treatment, 6 P(EDOTco-3TE) injected into cells via electroporation, untreated

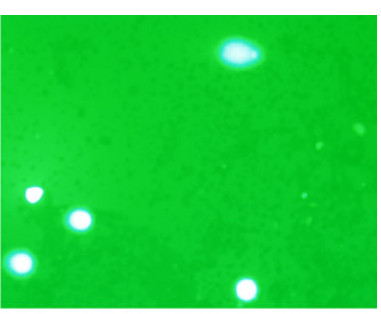

(3)
Mean \% Tail Intensity

- Standard Deviation of Mean $\%$ Tail Intensity

mean Tail Moment

- Standard Deviation of Tail Moment 
Fig. 4 Percent tail intensity and tail moment for BHK-21 cells

Fig. 5 Percent tail intensity and tail moment for Vero cells*

Fig. 6 Average percent tail intensity and tail moment for three cell lines

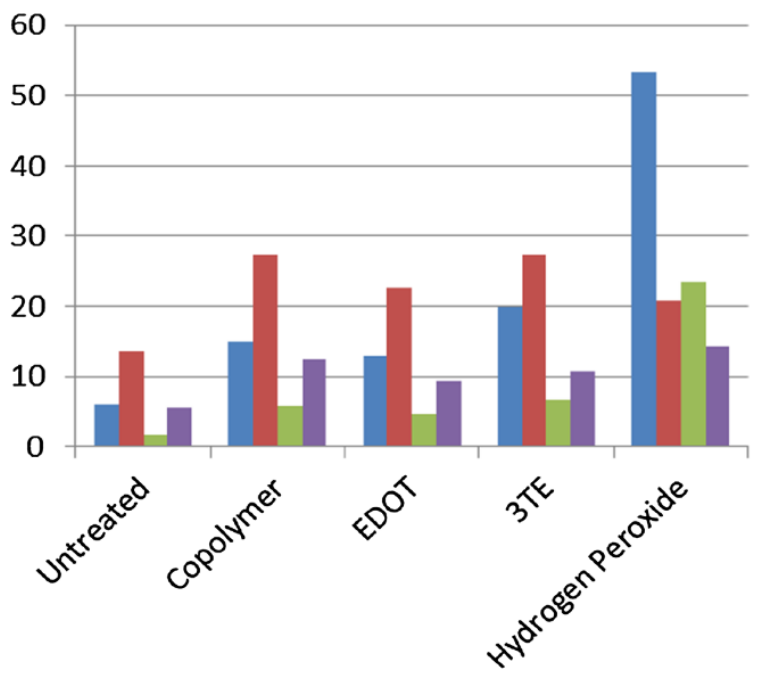

Mean \% Tail Intensity

Standard Deviation of Mean \% Tail Intensity

Mean Tail Moment

- Standard Deviation of Tail Moment

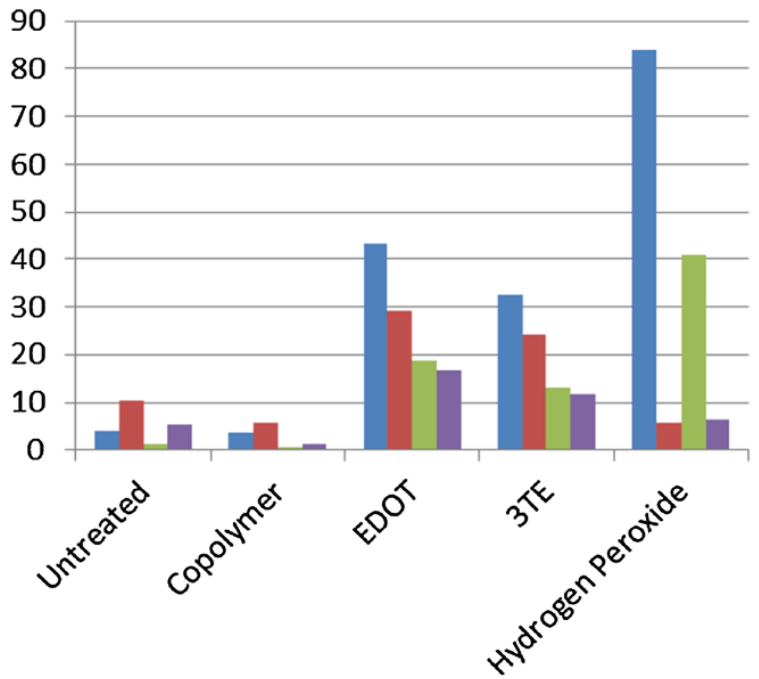

- Mean \% Tail Intensity

- Standard Deviation of \% Tail Intensity

Mean Tail Moment

- Standard Deviation of Tail Moment

Mean \% Tail Intensity

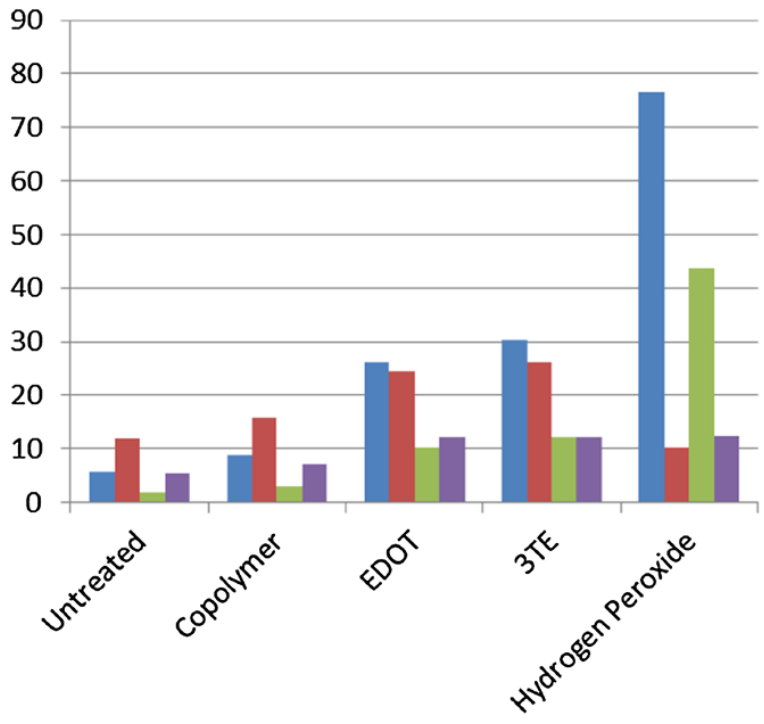

- Average Standard Deviation of Mean \% Tail Intensity for three cell lines

Mean Tail Moment of for three cell lines

Average Standard Deviation of Mean Tail Moment for three cell lines 
and Ames test, the copolymer is considered to have low to no potential of toxicity.

Acknowledgments This project was supported in part by an appointment to the Research Participation Program at the Winchester Engineering and Analytical Center, US Food and Drug Administration, administered by the Oak Ridge Institute for Science and Education through an interagency agreement between the US Department of Energy and FDA. This study was a collaborative project with US Food and Drug Administration, Massachusetts Institute of Technology, and Natick Army Labs.

Open Access This article is distributed under the terms of the Creative Commons Attribution License which permits any use, distribution, and reproduction in any medium, provided the original author(s) and the source are credited.

\section{References}

Ames BN, Durston WE, Yamasaki E, Lee FD (1973a) Carcinogens are mutagens: a simple test system combining liver homogenates for activation and bacteria for detection. Proc Natl Acad Sci 70(8):2281-2285 http://www.pnas.org/content/70/8/2281.abstract

Ames BN, Lee FD, Durston WE (1973b) An improved bacterial test system for the detection and classification of mutagens and carcinogens. Proc Natl Acad Sci 70(3):782-786 http://www. pnas.org/content/70/3/782.abstract

Asplund M, Thaning E, Lundberg J, Sandberg-Nordqvist AC, Kostyszyn B, Inganas O, von HH (2009) Toxicity evaluation of PEDOT/biomolecular composites intended for neural communication electrodes. Biomed Mater 4(4):045009

Bhattacharyya D, Senecal K, Marek P, Senecal A, Gleason KK (2011) High surface area flexible chemiresistive biosensor by oxidative chemical vapor deposition. Adv Funct Mater 21(22):4328-4337. doi:10.1002/adfm.201101071

Bhattacharyya D, Howden RM, Borrelli DC, Gleason KK (2012) Vapor phase oxidative synthesis of conjugated polymers and applications. J Polym Sci 50(19):1329-1351. doi:10.1002/polb. 23138

Forster R, Green MH, Priestley A (1980) Optimal levels of S9 fraction in the Ames and fluctuation tests: apparent importance of diffusion of metabolites from top agar. Carcinogenesis 1(4):337-346

Genies C, Maitre A, Lefebvre E, Jullien A, Chopard-Lallier M, Douki $T$ (2013) The extreme variety of genotoxic response to benzo[a]pyrene in three different human cell lines from three different organs. PLoS One 8(11):e78356

Hakura A, Suzuki S, Sawada S, Sugihara T, Hori Y, Uchida K, Kerns WD, Sagami F, Motooka S, Satoh T (2003) Use of human liver
S9 in the Ames test: assay of three procarcinogens using human S9 derived from multiple donors. Regul Toxicol Pharmacol 37(1):20-27

Hakura A, Shimada H, Nakajima M, Sui H, Kitamoto S, Suzuki S, Satoh T (2005) Salmonella/human S9 mutagenicity test: a collaborative study with 58 compounds. Mutagenesis 20(3):217-228

Hood S (2013) Environmental swab information. Torosian, Stephen and Hebert, Amanda

Howden RM, McVay ED, Gleason KK (2013) oCVD poly(3,4ethylenedioxythiophene) conductivity and lifetime enhancement via acid rinse dopant exchange. J Mater Chem A 1(4):1334-1340. doi:10.1039/C2TA00321J

Luo SC, Mohamed AE, Tansil NC, Yu HH, Gao S, Kantchev EA, Ying JY (2008) Poly(3,4-ethylenedioxythiophene) (PEDOT) nanobiointerfaces: thin, ultrasmooth, and functionalized PEDOT films with in vitro and in vivo biocompatibility. Langmuir 24(15):8071-8077

McGraw S, Alocilja E, Senecal A, Senecal K (2012a) Synthesis of a functionalized polypyrrole coated electrotextile for use in biosensors. 1: 466

McGraw S, Alocilja E, Senecal K, Senecal A (2012b) A resistance based biosensor that utilizes conductive microfibers for microbial pathogen detection. Open J Appl Biosens 1

Miriani RM, Abidian MR, Kipke DR (2008) Cytotoxic analysis of the conducting polymer PEDOT using myocytes. Conference proceedings Annual International Conference of the IEEE Engineering in Medicine and Biology Society. IEEE Eng Med Biol Soc 2008:1841-1844

Moral-Vico J, Sanchez-Redondo S, Lichtenstein MP, Sunol C, CasanPastor N (2014) Nanocomposites of iridium oxide and conducting polymers as electroactive phases in biological media. Acta Biomater

Mortelmans K, Zeiger E (2000) The Ames Salmonella/microsome mutagenicity assay. Mutat Res 455(1-2):29-60

Olive PL, Banath JP (1995) Sizing highly fragmented DNA in individual apoptotic cells using the comet assay and a DNA crosslinking agent. Exp Cell Res 221(1):19-26

Olive PL, Banath JP, Durand RE (1990a) Detection of etoposide resistance by measuring DNA damage in individual Chinese hamster cells. J Natl Cancer Inst 82(9):779-783

Olive PL, Banath JP, Durand RE (1990b) Heterogeneity in radiationinduced DNA damage and repair in tumor and normal cells measured using the "comet" assay. Radiat Res 122(1):86-94

Speit G, Hartmann A (2006) The comet assay: a sensitive genotoxicity test for the detection of DNA damage and repair. Methods Mol Biol 314:275-286

Trevigen Inc. (2012) CometAssay

Wessner DR, Maiorano PC, Kenyon J, Pillsbury R, Campbell AM (2000) Spot-overlay Ames test of potential mutagens. Assoc Biol Lab Educ 22:1-18 